\title{
Model Aplikasi Company Profile Berbasis Multimedia Studi Kasus : SMP Muhammadiyah 17
}

\author{
Hendra Bayu Suseno \\ ${ }^{a}$ Staf Pengajar Fakultas Sains dan Teknologi Program Studi Teknik Informatika \\ Universitas Islam Negeri Syarif Hidayatullah Jakarta \\ Tel : (021) 7493547 Fax : (021) 7493547 \\ e-mail:bayu_2169@yahoo.com
}

\begin{abstract}
The education development growth fastly made competition between school. This competition made the educational department chooses strategically decision for good education. For that reason good promotion and good publication is very needed in order to that school is famous with us, the one solution is made company profile interactive which made by macromedia flash $m x$ 2004. And also for supported the design the writer made storyboard, flowchart, navigation structure and user interface for build up application.
\end{abstract}

\section{Keywords :}

Multimedia, Story board, navigation structure, flowchart, and user interface

\section{PENDAHULUAN}

Profil Sekolah merupakan suatu media bagi masyarakat untuk mempublikasikan tentang suatu sekolah kepada calon siswa atau siswi yang akan bersekolah di suatu sekolah menengah pertama atau sekolah menengah atas dimana profil sekolah ini bertujuan untuk memudahkan calon siswa atau siswi lebih mengenal sekolah yang akan mereka daftarkan apakah sekolah yang akan mereka daftarkan merupakan sekolah yang mempunyai predikat baik atau tidak terhadap masyarakat atau pun kalangan luas.

Penggunaan multimedia mampu membuat suatu terobosan baru dalam menciptakan dinamika kemasan data dan informasi dengan cara yang berbeda, bukan dengan teks statis tetapi dengan animasi teks, gambar, suara, serta video. Yaitu dengan menggunakan Flash.

Biasanya sebuah profil sekolah dibuat di atas selembar brosur atau barang cetakan lainnya. Tetapi dengan adanya perkembangan teknologi yang ada pada saat ini penulis membuat sebuah profil sekolah ke dalam bentuk media yang lain yang lebih menarik, yaitu dengan menggunakan animasi flash.

Namun banyaknya siswa yang berminat untuk masuk pada suatu sekolah tanpa mengetahui banyak informasi tentang sekolah yang akan mereka daftarkan maka para calon siswa atau siswi akan berfikir apakah sekolah yang akan mereka daftarkan itu berkualitas atau tidak dari segi apapun mengenai sekolah yang akan mereka daftarkan, oleh karena itu penulis mencoba membuat model aplikasi profil sekolah pada smp Muhammadiyah 17 yang dapat memberikan penjelasan tentang sekolah ini kepada para calon siswa dan siswi yang akan bersekolah di sekolah tersebut.

\section{Rumusan masalah}

Berdasarkan latar belakang tersebut dapat dirumuskan bahwa permasalahan yang ada adalah : 
1. Bagaimana membuat suatu aplikasi company profil berbasis multimedia yang dapat membantu para calon siswa atau siswi untuk mengetahui lebih jelas tentang sekolah smp Muhammadiyah 17 ?

2. Bagaimana merancang tampilan model aplikasi company profile berbasis multimedia sehingga dapat menarik minat calon siswa-siswi untuk melanjutkan pendidikan di smp Muhammadiyah 17 ?

\section{Tujuan Penelitian}

Dalam penelitian ini, penulis menguraikan tujuan dan kegiatan dari penelitian yang akan dibahas, yaitu merancang atau mendesain sebuah tampilan profil pada smp Muhammadiyah 17

\section{Manfaat Penelitian}

Bagi lembaga pendidikan atau Universitas yaitu sebagai pengembangan ilmu pendidikan. Bagi pengguna sebagai informasi, khususnya bagi siswa atau siswi yang mempunyai minat untuk bersekolah pada smp Muhammadiyah 17.

\section{LANDASAN PEMIKIRAN}

Multimedia adalah penggunaan komputer untuk menampilkan informasi yang merupakan gabungan dari teks, grafik, audio dan video sehingga membuat pengguna dapat bernavigasi, berkreasi dan berkomunikasi dengan komputer.

Untuk membuat aplikasi multimedia, diperlukan penggabungan dari beberapa elemen, yaitu teks, gambar, grafik, animasi, suara, dan video.

\section{METODOLOGI PENELITIAN}

Penelitian ini merupakan penelitian rekayasa sistem dengan metode SDLC (System Development Life Cycle) berupa perancangan storyboard, desain struktur navigasi berupa hirarki menu, perancangan flowchart, dan perancangan antarmuka (user interface).

\subsection{Instrumen Penelitian}

Data dan informasi mengenai sekolah SMP Muhammadiyah 17 untuk dintegrasikan dalam sistem.

Komputer (Personal Computer) dengan spesifikasi: Pentium II, RAM 64 MB, HDD 6 GB untuk menjalankan perangkat lunak Macromedia Flash MX 2004 yang digunakan sebagai perangkat utama pembuatan model aplikasi company profile. Hal ini dilakukan dengan mempertimbangkan kemudahan dalam pengintegrasian antara teks, grafik, audio dan video.

\section{ANALISIS DATA}

Deskripsi konsep perancangan profil SMP Muhammadiyah 17 seperti tabel berikut

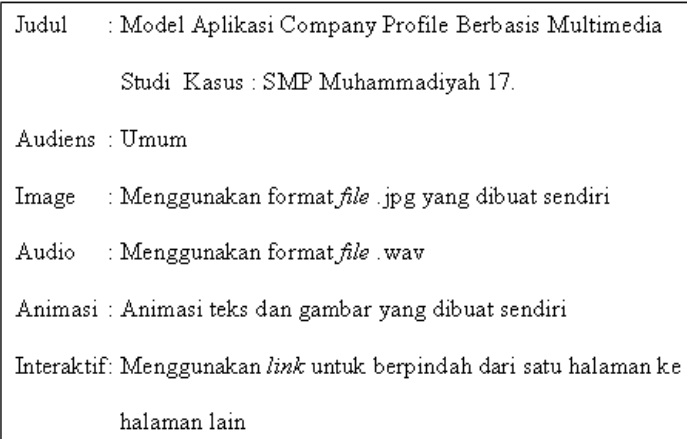

Tabel 1. Deskripsi konsep aplikasi

\subsection{Perancangan Storyboard}

Storyboard merupakan deskripsi tiap scene (tampilan), dengan mencantumkan semua obyek multimedia dan link ke scene lain. Secara umum rancangan storyboard yang dihasilkan penulis terdiri dari:

1. Scene $1 \rightarrow$ home

Menampilkan menu program

2. Scene $2 \rightarrow$ Sejarah

Menampilkan sejarah sekolah

3. Scene $3 \rightarrow$ Visi \& Misi

Menampilkan visi dan misi Sekolah

4. Scene $4 \rightarrow$ Program Kelas

Menampilkan program kelas

5. Scene $5 \rightarrow$ Fasilitas

Menampilkan fasilitas yang ada pada Sekolah

6. Scene $6 \rightarrow$ Staff 
Menampilkan Struktur organisasi yayasan (sekolah)

7. Scene $7 \rightarrow$ Ekstrakurikuler

Menampilkan kegiatan siswa yang ada di sekolah

8. Scene $8 \rightarrow$ Galeri photo

Menampilkan photo - photo sekolah

9. Scene $9 \rightarrow$ Alamat sekolah

Menampilkan alamat kontak sekolah

\subsection{Perancangan Flowchart}

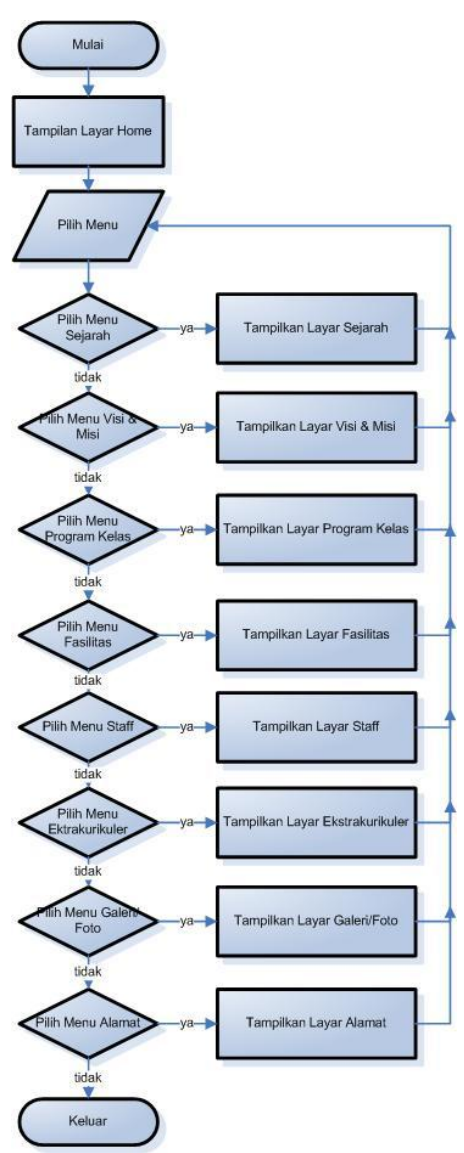

Gambar 1. Flowchart

\subsection{Perancangan Struktur Navigasi}

Perancangan struktur navigasi pembuatan model aplikasi company profile menggunakan hierarchiecal model. Pada model ini dapat dilihat penggunaan scene 1 yang dihubungkan dengan scene 2 . Kemudian scene 2 mempunyai hubungan dengan scene 3, scene 4, scene 5, scene 6 , scene 7 , dan scene 8 . Untuk lebih jelasnya dapat dilihat pada Gambar 2 berikut :

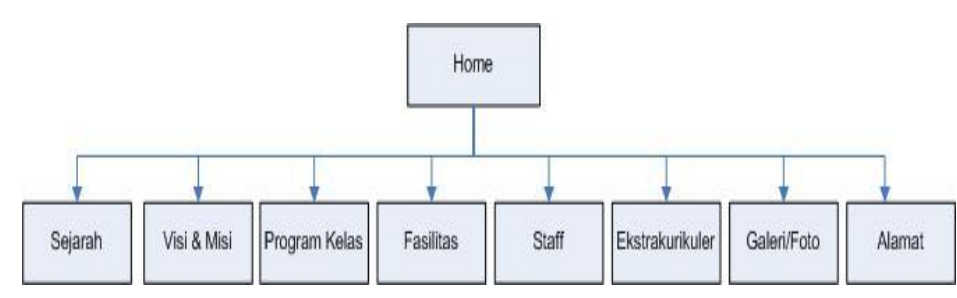

Gambar 2. Struktur Navigasi

\subsection{Perancangan Antarmuka Pemakai (User Interface)}

Rancangan antarmuka pemakai (user interface) yang akan ditampilkan pada aplikasi multimedia ini akan disesuaikan dengan kebutuhan pengguna yang akan melihat informasi yang mereka butuhkan. Pada program aplikasi terdapat delapan rancangan layar, yaitu :

1. Rancangan menu utama (Home)

Rancangan ini berfungsi sebagai tampilan utama yang menyediakan beberapa tombol menu yaitu : Sejarah, Visi \& Misi, Program kelas, Fasilitas, Staff, Ekstrakulikuler, Galeri photo, Alamat dan juga tombol untuk sound dan tombol exit (keluar program).

2. Rancangan Menu Sejarah

Pada rancangan layar ini akan menampilkan tombol sejarah untuk melihat sejarah smp Muhammadiyah 17

3. Rancangan Menu Visi \& Misi

Pada rancangan layar ini akan menampilkan tombol visi \& misi untuk melihat visi \& misi dari smp Muhammadiyah 17

4. Rancangan Menu Program kelas

Pada rancangan layar ini akan menampilkan tombol program kelas untuk melihat program kelas apa saja yang ditawarkan oleh smp Muhammadiyah 17

5. Rancangan Menu Fasilitas

Pada rancangan layar ini akan menampilkan tombol fasilitas untuk melihat fasilitas apa saja yang ada di smp Muhammadiyah 17.

6. Rancangan Menu Staff

Pada rancangan layar ini akan menampilkan tombol staff di mana 
jumlah staff - staff yang ada pada smp Muhammadiyah 17.

7. Rancangan Menu Ekstrakulikuler (ekskul)

Pada rancangan layar ini akan menampilkan tombol ekskul untuk melihat kegiatan ekskul apa saja yang ada di smp Muhammadiyah 17.

8. Rancangan Menu Galeri photo

Pada rancangan layar ini akan menampilkan tombol Galeri photo untuk melihat photo - photo yang ditampilkan pada galeri photo.

9. Rancangan Menu Alamat

Pada rancangan layar ini akan menampilkan tombol alamat untuk melihat alamat pada smp Muhammadiyah 17.

Adapun rancangan tampilan layar utama halaman utama (home) sebagai berikut:

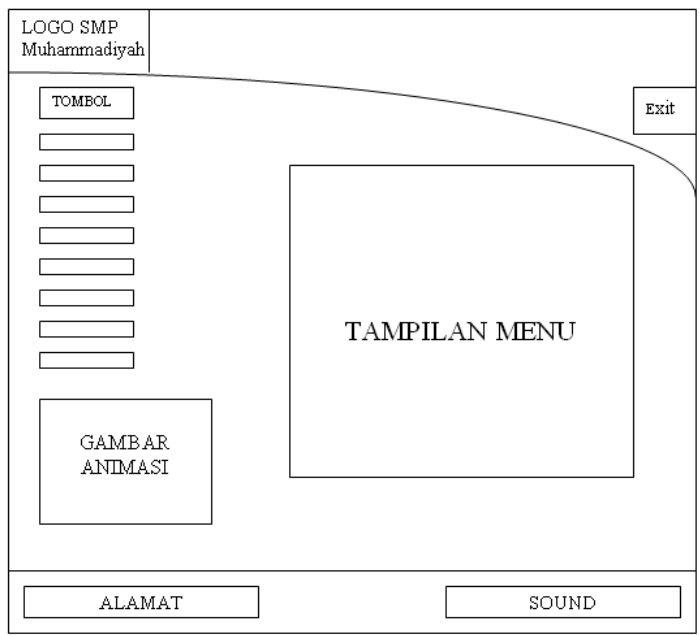

Gambar 3. Rancangan tampilan layer utama

\subsection{Implementasi Program}

Tampilan awal program berisi menu pilihan diantaranya sejarah, visi dan misi, program kelas, fasilitas, staff, ekstrakurikuler, galeri foto, alamat dan my profile

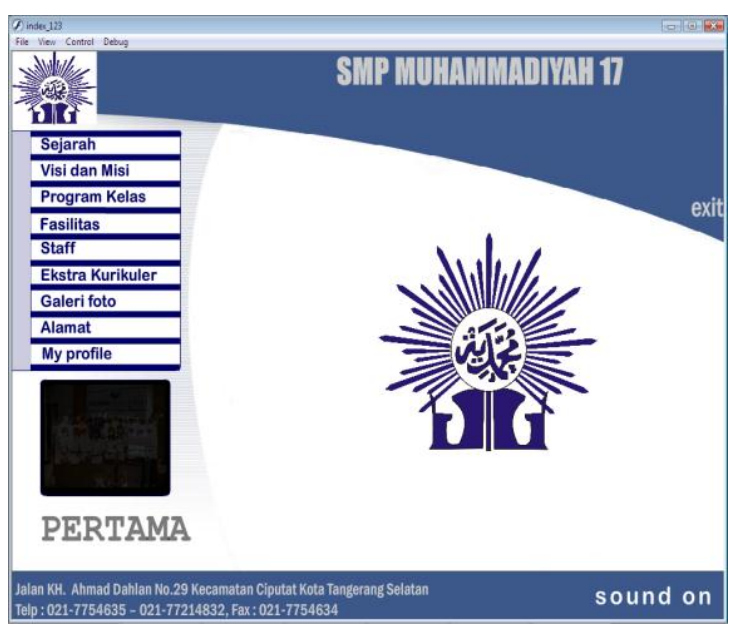

Gambar 4. Tampilan Awal aplikasi

Tampilan menu sejarah berisi tentang sejarah SMP Muhammadiyah 17

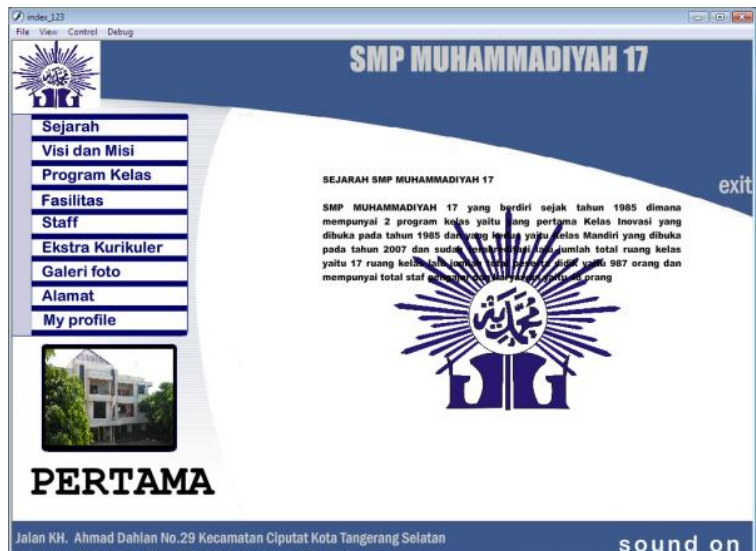

Gambar 5. Tampilan Sejarah

Tampilan visi dan misi berisi tentang visi dan misi SMP Muhammadiyah 17

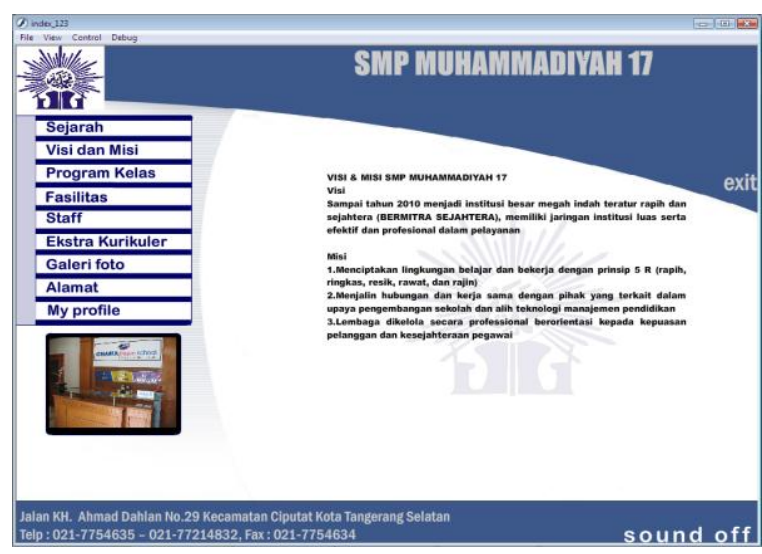

Gambar 6. Tampilan Visi dan Misi 
Tampilan program kelas berisi tentang penawaran program kelas yang ada pada SMP Muhammadiyah 17

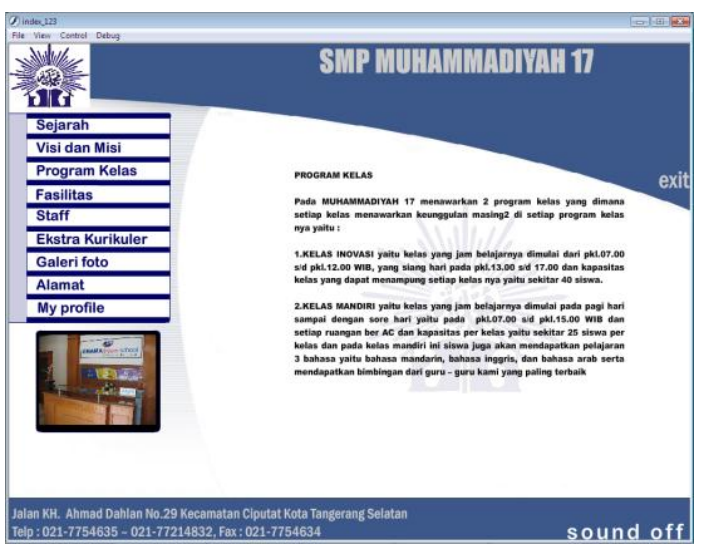

Gambar 7. Tampilan Program kelas

Tampilan fasilitas berisi tentang fasilitas yang ada pada SMP Muhammadiyah 17

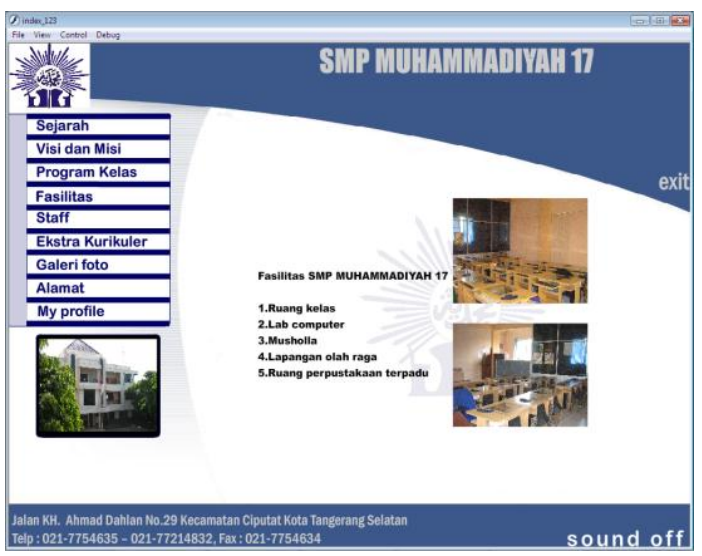

Gambar 8. Tampilan Fasilitas

Tampilan staff berisi jumlah staff yang ada pada SMP Muhammadiyah 17

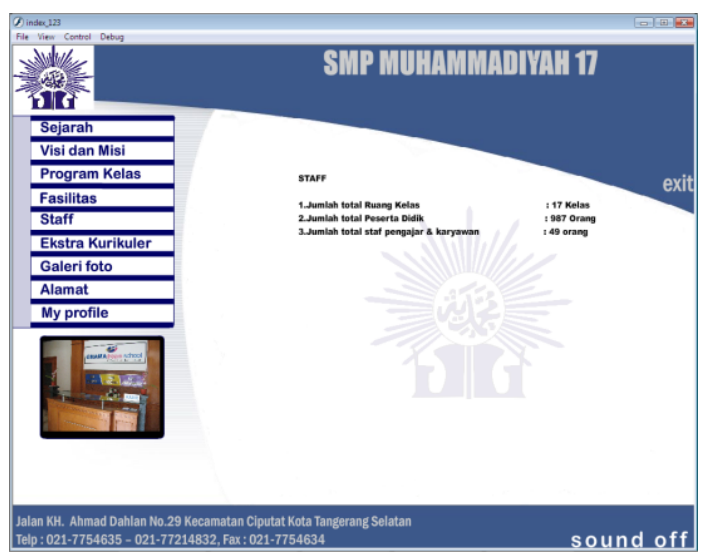

Gambar 9. Tampilan Staff
Tampilan ekstrakurikuler berisi tentang ekstrakurikuler yang ada pada SMP Muhammadiyah 17

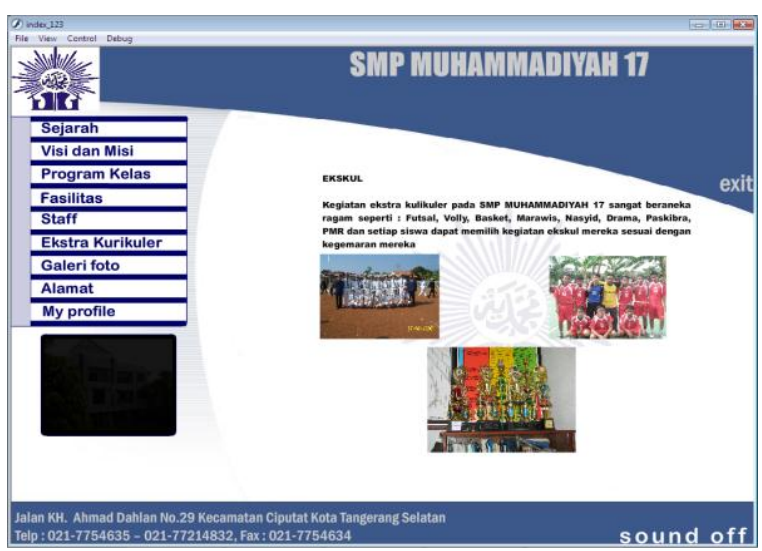

Gambar 10. Tampilan Ekstrakurikuler

Tampilan galeri foto berisi foto yang berkaitan dengan SMP Muhammadiyah 17

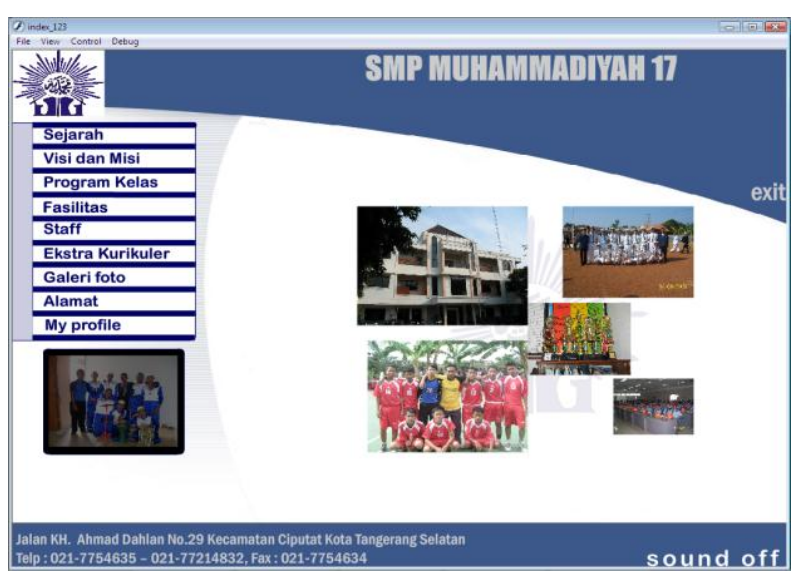

Gambar 11. Tampilan Galeri Foto

Tampilan alamat berisi alamat SMP Muhammadiyah 17

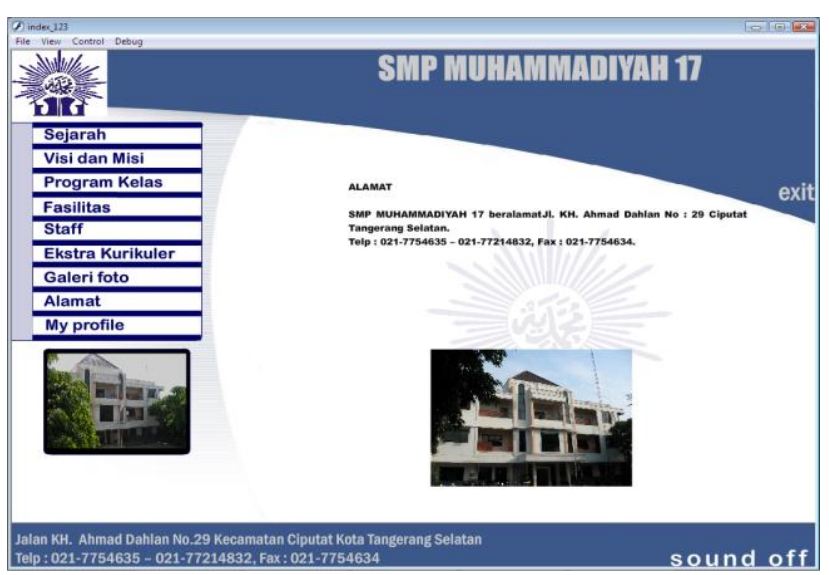

Gambar 12. Tampilan Alamat 


\subsection{Implikasi Penelitian}

Aspek manajerial dari penelitian ini adalah penyediaan $C D$ interaktif autorun dimana $C D$ ini dapat memberikan informasi yang terkait dengan SMP Muhammadiyah 17.

Adanya hasil dari penelitian ini dapat mengefisienkan waktu, menghemat biaya, dan dapat melakukan promosi ke orang tua serta calon siswa dan siswi yang akan sekolah pada SMP Muhammadiah 17

Aspek sistem yang digunakan dapat menggunakan sistem operasi berbasis microsoft windows seperti microsoft windows 97, 98, XP, 2000, dan 2003 server.

Aspek hardware dapat menggunakan pentium $250 \mathrm{Mhz}$ dengan ram $64 \mathrm{Mb}$ serta aplikasi ini dapat dihubungkan dengan jaringan (Networking).

\section{KESIMPULAN}

Dari analisa yang telah dipaparkan, dapat diambil kesimpulan :

1. Model aplikasi company profile ini dapat dibangun dengan menggunakan perangkat lunak Macromedia Flash MX dalam pengintegrasian teks, suara, gambar dan video.

2. Dalam membuat suatu model aplikasi company profile berbasis multimedia diperlukan komponen yang digunakan dalam aplikasi berupa tampilan-tampilan menu navigasi, dimana saling menghubungkan satu sama lain untuk melihat data-data yang ada pada perancangan aplikasi smp Muhammadiyah 17 berbasis multimedia.

3. Dalam perancangan company profile smp Muhammadiyah 17 penulis menggunakan metode SDLC (System Development Life Cycle). SDLC (System Development Life Cycle) merupakan suatu metode pengembangan system yang terdiri dari tahapan-tahapan yang membentuk siklus, disebut siklus hidup karena sistem dapat diperbaharui sesuai dengan kebutuhan (born-live-die-replace), aktivitas dari siklus hidup ini disebut tahapan atau fase dan tahapan yang digunakan yaitu: Analisa Sistem, Perancangan Sistem, Implementasi Sistem, Operasi dan Pemeliharaan.

\section{REFERENSI}

[1]. Jogiyanto. (1995) Pengenalan Komputer, Andi Offset Yogyakarta, 1995

[2]. Fred T, Hofstetter. (2001). Multimedia Literac. Third Edition. McGrawHill, 2001

[3]. Hendratman, Hendi. (2007). The Magic Of Adobe After Effects. Informatika, 2007

[4]. John A.McCormick. (1995). Multimedia System. McGraw-Hill, 1995

[5]. Suyanto, M. (2004). Analisis dan Desain Aplikasi Multimedia Untuk Pemasaran. Andi Offset : Yogyakarta, 2004

[6]. Suyanto, M. (2005). Multimedia Alat untuk Meningkatkan Keunggulan Bersaing, Yogyakarta: Andi Offset, 2005

[7]. Turban, McLean, Wetherbe. (2002). Information Technology For Management. Third Edition. John Wiley \& Sons Inc, 2002

[8]. Baksin, Askurifai. (2003). Membuat Film Indie Itu Gampang. Bandung: Katarsis, 2003

[9]. Baksin, Askurifai. (2009). Videografi Operasi Kamera dan Pengambilan Gambar. Bandung: Widya Padjadjaran, 2009

\section{COPYRIGHT}

(C)2010 